\title{
Teaching with luck: \\ uma proposta de ensino de língua inglesa baseada no conto Luck, de Mark Twain
}

\author{
Teaching with luck: \\ una propuesta de enseñanza para la Lengua Inglesa basada \\ en el cuento Luck, de Mark Twain
}

\author{
Teaching with luck: \\ an English teaching proposal based on the tale Luck, by \\ Mark Twain \\ Dhandara Capitani ${ }^{1}$ \\ Marlene Neri Sabadin ${ }^{2}$ \\ Tatiane Cristina Becher ${ }^{3}$
}

\begin{abstract}
RESUMO: Neste artigo, apresenta-se uma proposta de ensino de língua inglesa que se utiliza do conto "Luck", do autor norte-americano Mark Twain, com o intuito de demonstrar como uma obra literária original, provinda da literatura de língua inglesa, pode ser trabalhada em turmas de ensino médio de escolas públicas regulares, vinculando o ensino da língua estrangeira ao ensino da literatura de língua inglesa, de maneira dinâmica e diferenciada, mediada por diversificados recursos visuais e interativos. O recorte aqui apresentado pertence a uma sequência didática que foi aplicada em duas turmas de segundo ano do ensino médio de uma escola pública regular, as quais mostraram-se participativas e engajadas com as atividades propostas. Um questionário foi aplicado ao final da aplicação da proposta, por meio do qual foi possível averiguar as percepções positivas dos alunos quanto à prática. 0 trabalho escrito sobre o processo de desenvolvimento e de aplicação dessa proposta de ensino foi aportado em autores como Bezerra (2010), Bordini e Aguiar (1993), Gantier (1974), Polidório (2004), Smith (1967), dentre outros.
\end{abstract}

PALAVRAS-CHAVE: Ensino. Língua inglesa. Literatura. Sequência didática.

\footnotetext{
${ }^{1}$ Professora do curso de Letras Português/Inglês e Respectivas Literaturas (UNIOESTE), Mestre em Letras (UNIOESTE), Doutoranda em Letras (UNIOESTE), Universidade Estadual do Oeste do Paraná. E-mail: dhandaracapitani@gmail.com

${ }^{2}$ Professora do curso de Letras Português/Inglês e Respectivas Literaturas (UNIOESTE), Mestre em Letras (UNIOESTE), Universidade Estadual do Oeste do Paraná, Doutora em Letras (UFBA), Universidade Federal da Bahia. E-mail: sabamane@ yahoo.com.br

${ }^{3}$ Licenciada em Letras Português/Inglês e Respectivas Literaturas (UNIOESTE), Mestranda em Letras (UNIOESTE). E-mail: taati.becher@gmail.com
} 
RESUMEN: En este trabajo, se adjunta una propuesta de enseñanza para la Lengua Inglesa que se utiliza del cuento "Luck", del autor norteamericano Mark Twain, con el propósito de demostrar como una obra literaria original, proveniente de la literatura de la Lengua Inglesa, puede ser trabajada en las clases de enseñanza media en una escuela pública regular, vinculando la enseñanza de la lengua extranjera a la enseñanza de la literatura de la Lengua Inglesa, desde una dinámica diferente, mediante materiales visuales e interactivos. El fragmento presentado en este trabajo hace parte de una secuencia didáctica que fue aplicada en dos clases de según año de la enseñanza media de una escuela pública regular, las cuales se mostraran participativas y comprometidas con las actividades propuestas. Un cuestionario fue aplicado al final de las actividades, siendo posible averiguar las percepciones positivas de los estudiantes delante de la práctica. El trabajo escrito sobre el proceso de desarrollo y aplicación de esta propuesta se basó en los autores Bezerra (2010), Bordini y Aguiar (1993), Gantier (1974), Polidório (2004), Roulet (1978), Smith (1967), entre otros.

PALABRAS CLAVE: Enseñanza. Lengua Inglesa. Literatura. Secuencia didáctica.

ABSTRACT: In this article, an English teaching proposal is presented, which uses the tale "Luck", by the North American writer Mark Twain, with the intention of demonstrating how an original literary work, from English language literature, may be used in high school classes of public regular schools, in a dynamic and different manner, involving diversified visual and interactive resources. This piece of paper is part of a didatical sequence applied in two classes from the second grade of high school, in a regular public school, which were participative and involved with the activities proposed. A questionnaire was appplied at the end of the proposal's execution, which made it possible to verify the students' positive impressions about the practice. The written work about the process of development and implementation of this proposal was based in authors such as Bezerra (2010), Bordini e Aguiar (1993), Gantier (1974), Polidório (2004), Smith (1967), among others.

KEYWORDS: Teaching. English language. Literature. Didactical sequence.

\section{Introdução}

Este artigo trata de uma pesquisa realizada durante 0 estágio supervisionado, em que se utilizou uma abordagem de ensino de língua estrangeira atrelada ao ensino da literatura de língua inglesa de maneira dinâmica e motivadora. Para tanto, apresenta-se um recorte de uma proposta de sequência didática desenvolvida e aplicada por meio do conto "Luck", do autor norte-americano Mark Twain, para envolver diferentes didáticas de ensino de língua inglesa e de literatura de língua inglesa, buscando, a partir dessas atividades, apresentar contribuições às praticas educacionais norteadoras do ensino de língua inglesa na escola regular. 
Para que se proponha uma prática funcional para o ensino de língua inglesa, que considere a importância das variáveis envolvidas, as atividades propostas diferenciam-se em variados quesitos, como no uso da versão original de um texto provindo da literatura inglesa, sem utilizar de tradução nas atividades escritas, incentivando o processo de aprendizado por meio de exercícios que promovam momentos de prática do idioma em estudo.

Dessa maneira, a proposta apresentada possibilitou a criação e a elaboração de uma aula dinamicamente funcional e atraente que envolve tanto o ensino da língua inglesa como segunda língua (ESL), como o ensino da literatura. Sendo assim, as atividades criadas permeiam a prática das habilidades cognitivas de audição, leitura, fala e escrita no idioma em estudo, permitindo aos alunos que participem ativamente da proposta, otimizando, assim, o engajamento dos sujeitos envolvidos com seu processo de ensinoaprendizagem.

Todas as dinâmicas utilizadas justificam-se, primordialmente, pelo objetivo de tornar o ensino da língua na escola regular mais relevante, enfatizando as quatro macro habilidades: a fala, compreensão oral, a escrita e a leitura. Utilizou-se de interações dinâmicas, indução à compreensão da língua inglesa, frequente exposição do idioma aos alunos, objetos digitais de apresentação dinâmicos e diferenciados, dentre outros recursos, para que se desenvolvesse um grau elevado, dentro do possível, de contato com a língua inglesa durante os momentos em sala de aula destinados a tal prática, sempre de forma a envolver as quatro macro habilidades, em cada uma das atividades realizadas.

Esperava-se que, partindo dessa perspectiva, não só a dinamicidade da proposta aumente, mas que os alunos se sentissem mais motivados e capazes de aprender um idioma estrangeiro, e percebessem a riqueza da abordagem interdisciplinar ao se envolver o ensino da língua inglesa e da literatura de língua inglesa em uma mesma sequência didática. Para melhor percepção da visão dos alunos que participaram das aulas, um questionário foi aplicado ao 
fim da aplicação do trabalho em sala de aula, na intenção de averiguar as considerações a serem feitas pelos estudantes quanto à prática.

As teorias que embasaram o trabalho são provenientes de autores como Bezerra (2010), Bordini e Aguiar (1993), Gantier (1974), Polidório (2004), Smith (1967), dentre outros. Apresentam-se, também, algumas das atividades desenvolvidas e aplicadas em duas turmas de segundo ano do ensino médio de uma escola pública regular em Cascavel - PR, as quais se mostraram participativas e engajadas com as atividades propostas. 0 presente artigo encontra-se organizado a partir dos seguintes tópicos: o ensino do inglês como segunda língua (ESL) atrelado ao ensino da literatura de língua inglesa; a dinamicidade no processo de ensino/aprendizagem de uma língua estrangeira; práticas de ensino desenvolvidas para a proposta; a percepção dos alunos acerca da proposta; e, por fim, as reflexões acerca dos resultados da proposta aplicada.

\section{O ensino do inglês como segunda língua (ESL) atrelado ao ensino da literatura de língua inglesa}

A decisão de atrelar o ensino da língua inglesa ao ensino da literatura de língua inglesa decorre da intenção de possibilitar a apresentação de um trabalho ainda mais atrativo aos alunos, utilizando-se de um estudo interdisciplinar que otimiza o ensino de diferentes habilidades em uma mesma aula. Conforme embasamento em estudos da área, a possibilidade de se trabalhar a literatura e a língua vinculadas não apenas existe, como também representa uma rica diversidade de possibilidades a serem exploradas pelo professor.

Dentre as inúmeras possibilidades de tornar o trabalho com a língua inglesa e com a literatura ainda mais envolventes aos discentes, Polidório (2004) afirma que o uso da literatura no ensino de língua estrangeira pode auxiliar os alunos em situações reais, pois esta é uma das funções do texto literário: viabilizar o contato com fatos e realidades que coincidem com as 
próprias experiências pessoais. Quer dizer, literatura estaria representando a vida, assim como a língua se faz presente em toda e qualquer ação social, conforme afirma Bakhtin (1992, p. 280) "todas as esferas da atividade humana, por mais variadas que sejam, estão sempre relacionadas com a utilização da língua".

Segundo Bezerra (2010), o ensino de línguas, objeto de estudo em pesquisas desde as últimas décadas do século $X X$, é observado ora como um processo, considerando as estratégias de ensino e a interação entre professor e alunos, ora como produto, levando em conta análises de materiais didáticos, por exemplo. Dentro de tais estudos, é preciso considerar a necessidade de liames imprescindíveis entre as diferentes disciplinas, de forma a integrar a produção de conhecimentos das especialidades que formam um todo. Para tanto, por meio da prática interdisciplinar, o professor planeja o conteúdo de forma a promover uma aprendizagem simultânea dos saberes existentes entre diferentes disciplinas. Dessa forma, a abordagem interdisciplinar requer uma visão ampla e específica da língua, concomitantemente, durante o processo de ensino, sendo benefício da interdisciplinaridade a possibilidade de reordenação de conhecimentos diversos e posterior geração de conhecimento novo.

\footnotetext{
A interdisciplinaridade curricular se refere a uma dimensão mais ampla, capaz de incluir a interdisciplinaridade didática (que compreende a ideia de planejamento da organização, da prática e da avaliação educativa) e a interdisciplinaridade pedagógica (que se caracteriza pela atualização em sala de aula da interdisciplinaridade didática) (BEZERRA, 2010, p. 23).
}

As vantagens de se utilizar uma abordagem interdisciplinar mencionadas por autores como Bezerra (2010) consistem nas principais intenções pretendidas no desenvolvimento e aplicação das atividades apresentadas neste artigo. Neste sentido, algumas das considerações a serem levadas em conta para que se promova momentos reais de ensino/aprendizagem de língua e de literatura enquanto disciplinas interligadas são trazidas por Bezerra (2010), o qual menciona que, para que se utilize de um estudo interdisciplinar no ensino 
de línguas, professores e alunos devem estar conscientes de algumas concepções epistemológicas

Continua Bezerra (2010) que trabalhar com interdisciplinaridade não significa apenas unir diferentes conhecimentos entre áreas distintas para exercer determinado tema, mas sim estudar o objeto escolhido dentro de um conjunto por meio de uma visão holística do grupo, considerando que cada realidade requer uma configuração específica de trabalho. Não existem modelos pré-concebidos para o ensino interdisciplinar, dado que estes devem ser construídos em função do tema escolhido para ser explorado, dentro da situação específica em que esse tema e os participantes estão inseridos.

Ao considerarmos o trabalho com a língua e com a literatura, ressalta-se a habilidade de leitura e compreensão textual, as quais foram consideradas ao longo de toda a proposta aqui apresentada, assim como as outras macro habilidades existentes no ensino de línguas estrangeiras. Segundo Smith (1967), cada experiência de leitura deve ser transmitida ao aluno como uma atividade de comunicação com um verdadeiro propósito, envolvido por agradáveis associações. Não se lê apenas por ler, mas sim para que a comunicação seja possível, para que se possa saber o que outros têm a dizer. A leitura é uma ferramenta ou habilidade passível de uso para os mais diversos propósitos e, acima de tudo, a leitura realizada com intenção deve significar um momento agradável para aquele que lê.

De acordo com Bordini e Aguiar (1993, p. 13), "todos os livros favorecem a descoberta de sentidos, mas são os literários que o fazem de modo mais abrangente". Esta afirmação aporta-se no fato de que os materiais literários dão conta da totalidade do real, alcançando uma significação mais ampla do que a apresentada por textos informativos, que apresentam um conteúdo mais particular. A linguagem literária representa a essência da vida humana por meio dos processos histórico-político-sociais que traz consigo, representando o sentido humano atribuído à realidade pelo autor e permitindo trocas comunicativas entre diferentes grupos sociais. 
Para tanto, "[a] leitura pressupõe uma participação ativa do leitor na constituição de sentidos linguístico" (BORDINI; AGUIAR, 1993, p. 16), sendo que é papel do educador permitir ao aluno a possibilidade de vincular-se à realidade expressa por diferentes obras, construindo imagens mentais interligadas por meio da leitura de uma obra literária, apoiando-se no conteúdo verbal transmitido pelo autor e acessando conteúdos da própria consciência do aluno, não apenas intelectuais, mas emocionais e de seu desejo.

"The teaching of literature can be seen as a way of discussing many aspects of life. Furthermore, literature must be seen as social and relevant to the context of a society. ${ }^{14}$ (POLIDÓRIO, 2004, p. 37). Segundo Polidório (2004), professores de língua estrangeira devem sempre ressaltar a importância dos textos literários como textos socialmente relevantes; além disso, os textos literários podem ser mais atrativos aos alunos do que os textos de livros didáticos voltados ao ensino da língua. Tais conjecturas também instigaram a criação dessa sequência didática, ao apresentarmos uma prática não apenas de ensino/aprendizagem de língua inglesa, mas também de ensino de literatura.

\section{A dinamicidade no processo de ensino/aprendizagem de uma língua estrangeira}

O uso do livro didático em ambiente escolar necessita de complementação por meio de outros materiais e maior preparação por parte do professor que o utiliza. Um livro didático não deve ser considerado suficiente para tornar a aula um momento atraente e produtivo ao aluno.

Com relação ao ensino de línguas, as diretrizes presentes no Conseils pratiques pour l'enseigment de l'anglais', citado por Gantier (1974), partem das seguintes premissas: durante o ensino do idioma inglês, deve-se utilizar 0

\footnotetext{
4 "O ensino de literatura pode ser visto como uma forma de discutir muitos aspectos da vida. Além disso, a literatura deve ser vista como social e relevante ao contexto de uma sociedade." [Tradução nossa]

${ }^{5}$ Conseils pratiques pour l'enseignement de l'anglais, Paris, I.P.N., 1958, 14 p.
} 
"método direto" ou ativo, que se consolida com base nos princípios básicos de simplicidade e modéstia; "fazer pouco, mas fazer bem" (GANTIER, 1974, p. 2425). Destarte, solidificar o estudo do idioma em um conhecimento seguro da língua, tanto de vocabulário quanto gramatical, ao invés de construí-lo em bases pouco sólidas. Não se deve sacrificar a qualidade pela quantidade.

Além disto, ensinar a língua de maneira ativa e coletiva - ativa, no sentido de que o professor não deve poupar esforços no processo de ensino, e coletiva no sentido de que não deve ser o professor o único a trabalhar. Uma aula voltada a um monólogo do professor representa fracasso. Para alcançar a eficácia, o ensino deve estimular o grupo como um todo, fazendo com que todos os integrantes participem na produção e engajamento das atividades, consoante ao que se apresenta nos Parâmetros Curriculares Nacionais, denominados PCN, do Ensino Médio (BRASIL, 2000), que apontam a importância do domínio de língua(s) estrangeira(s) modernas(s) como instrumento de comunicação, acesso a informações e diferentes culturas, sendo que se deve pensar no ensino de línguas estrangeiras como uma competência abrangente e não estática, que promova real comunicação e que interligue-se com diferentes disciplinas da grade curricular.

Smith (1967) postula os princípios básicos do ensino criativo, os quais envolvem a utilização de um material novo, diferente, que apresente resultados únicos; o estímulo de diferentes processos de pensamento; o uso de situações sem final planejado; resultados imprevisíveis; a criação e desenvolvimento de ideias dos próprios alunos; a consideração do processo como tão importante quanto o resultado; o encorajamento ao aprendizado partindo do próprio aluno; o desenvolvimento da criatividade; a exploração de ideias e objetos; etc.

Por todos esses motivos mencionados, a proposta apresentada neste artigo buscou, em todos os momentos, trazer a participação dos alunos para uma aula ativa e coletiva, de forma a alternar entre as vozes do professor e dos alunos, assim como alternar os momentos de prática. Considera-se que o aluno deve participar do processo de ensino/aprendizagem de maneira ativa, participativa e, consequentemente, engajada. 
Para possibilitar tal engajamento, um dos aparatos mais vantajosos nesse sentido são os Objetos Digitais de Ensino/Aprendizagem (ODEA), que, com adequado direcionamento do professor, tendem a dinamizar o processo de ensino/aprendizagem, de forma a possibilitar uma participação mais intensa do aluno durante a aula. Na proposta apresentada, alguns dos ODEA mais utilizados com essa finalidade foram slides com efeitos interativos, gifs, vídeos, áudios, dentre outros.

Sobre o uso de ODEA no ensino de línguas, Motter (2013) afirma que o ambiente mais explorado por escolas de idiomas, instituições privadas e escolas públicas é o infinito espaço digital do qual hoje dispomos. Por meio das opções de criação disponíveis em ambientes virtuais, a noção de transmissão do conhecimento pronto é superada, enquanto a construção do conhecimento por meio da interação é promovida. É primordial que um dos pontos principais a ser buscado pelo professor, particularmente na escola pública, é a verdadeira compreensão de que existem, de fato, inúmeras possibilidades de se desenvolver adequadamente diferentes habilidades cognitivas do aluno. A ênfase não deve, portanto, acontecer na escrita. Além de materiais textuais, outros eventos pertencentes à rotina do aprendiz podem ser utilizados na otimização de seu processo de aprendizagem, como sons, luzes, cores, imagens, linguagem hipertextual, etc. Segundo a autora, "A língua verbal-oral conta, hoje, com recursos visuais e sonoros que não se aplicam à modalidade verbal-escrita pela qualidade espacial que os meios digitais propiciam" (MOTTER, 2013, p. 203).

\section{Práticas de ensino desenvolvidas e aplicadas}

A proposta da sequência didática elaborada e apresentada no presente artigo envolveu diferentes questões relacionadas ao desenvolvimento cognitivo do aprendiz. Uma dessas questões principais foi promover o maior aproveitamento possível do tempo com os alunos durante as aulas de inglês na escola regular. Utilizamo-nos da designação das atividades como uma 
"sequência didática" no sentido em que, conforme Dolz, Noverraz e Schneuwly (2004), caracteriza-se como "um conjunto de atividades escolares organizadas de maneira sistemática, em torno de um gênero textual oral ou escrito" (DOLZ; NOVERRAZ; SCHNEUWLY, 2004, p. 97).

A sequência didática foi aplicada em duas turmas do ensino médio de uma escola pública regular, com a duração de 8 horas de aula em cada turma, distribuídas em 5 semanas diferentes. Apesar de ter sido elaborada e aplicada, para este trabalho, em turmas de ensino médio regular de uma escola pública, a sequência de atividades produzida pode ser utilizada em diferentes âmbitos por educadores de língua inglesa e de literatura de língua inglesa, como cursinhos de inglês, instituições privadas de ensino de diferentes naturezas, minicursos, workshops, etc.

Com relação ao material literário escolhido para a elaboração da sequência de atividades aqui apresentadas, utilizou-se o conto Luck, de Mark Twain, renomado autor norte-americano. $O$ enredo do conto Luck traz a história de um capitão inglês chamado Lord Arthur Scoresby, a partir de uma conversa entre o narrador e um clérigo, os quais falam sobre Scoresby durante todo o conto. De acordo com o clérigo, Scoresby é completamente tolo e, apesar de sua incompetência, é sortudo ao ponto de ser aclamado como herói por seus feitos de guerra, todos conquistados apenas por pura sorte, conforme a perspectiva do clérigo.

Porém, há mais do que uma interpretação possível na história: o clérigo pode estar transmitindo a verdade por meio de seus relatos, e Scoresby seria, de fato, apenas um general com muita sorte, mas nenhuma habilidade de batalha; há, também, a possibilidade de a visão do clérigo quanto a Scoresby ser limitada por sua perspectiva pessoal, o que significaria que, na realidade, Scoresby desperta sentimentos de inveja no clérigo, o qual poderia estar inventando todo esse discurso de que Scoresby é apenas um sujeito de muita sorte e sem qualquer habilidade real - quando, na verdade, Scoresby é, de fato, um herói de guerra, mas o clérigo se sente extremamente ameaçado e invejoso por tal realidade. Assim, todos os seus relatos ao longo do conto são 
fruto de uma imagem que o clérigo acredita ser a verdade sobre o general e que não consegue mudar, possivelmente por inveja, para desmerecer 0 valoroso herói de guerra.

A escolha do conto para essa sequência de atividades foi decisiva por diversos fatores. Entre eles, a ambiguidade de interpretações possíveis à história, o que criou a possibilidade de discussões interessantes sobre as opiniões divergentes entre os alunos; ademais, a possibilidade de envolver todas as atividades com o tema "sorte", sobre o qual vários detalhes apresentados durante as aulas foram baseados. A sorte não apenas é o título do conto (Luck), mas também se faz presente como elemento simbólico ao longo da história, por meio dos relatos do clérigo quanto às inúmeras ocasiões em que Scoresby tivera tremenda sorte em suas batalhas.

Desde a primeira aula, questionou-se sobre a sorte dos alunos, quanta sorte consideravam possuir, para qual outro aluno da turma eles desejariam sorte, etc. Vários elementos de analogia à questão da sorte foram utilizados, como a imagem de um trevo e a cor verde, creditados à simbologia da sorte.

Para a compreensão do conto a ser lido, primeiramente trabalhou-se, de diversas maneiras, o vocabulário específico a ser apresentado em cada trecho da história. No exemplo aqui trazido, essa apresentação do vocabulário foi feita a partir da exposição em slides. Essa prática de assimilação de definições das palavras corresponde à base da aplicação da maioria dos exercícios desta sequência. Tal metodologia foi escolhida pelo fato de o material literário utilizado se tratar de um texto original, sem qualquer adaptação, que, portanto, apresenta termos que requerem um conhecimento mais avançado do idioma para que a compreensão seja possível.

Os exercícios que focalizam esse vocabulário avançado em específico, antes de se partir à interpretação em grupo do texto, representam não apenas uma necessidade no momento da aplicação, mas também um fator facilitador e motivador para o aluno que, no momento em que se volta ao texto e compreende as palavras que foram anteriormente explicitadas, desfruta da possibilidade de sentir-se mais capacitado a compreender o texto, mesmo 
sabendo que se trata de um material mais desafiador do que um texto desenvolvido especificamente para o seu nível de proficiência, pois consegue entender várias das palavras que aparecem ao longo da leitura.

$\mathrm{Na}$ apresentação do vocabulário em slides, os chamados GIFs foram utilizados de maneira intensa nesta atividade. Conforme descrição de Brito (2013), para o site TechTudo, denomina-se GIF um formato de imagens popular na internet, lançado em 1987 pela CompuServe, com a intenção de disponibilizar um formato de imagens interativas com cores. A sigla GIF vem do inglês "Graphics Interchange Format" ou, em português, "formato de intercâmbio de gráficos". Como fator de contribuição para esta atividade, o artifício do cômico também foi explorado, acarretado pela escolha das figuras animadas trazidas nos GIFs, conforme apresentado nas figuras 1 e 2, a seguir.

\section{Figura 1- Slide de apresentação da palavra "generation"}

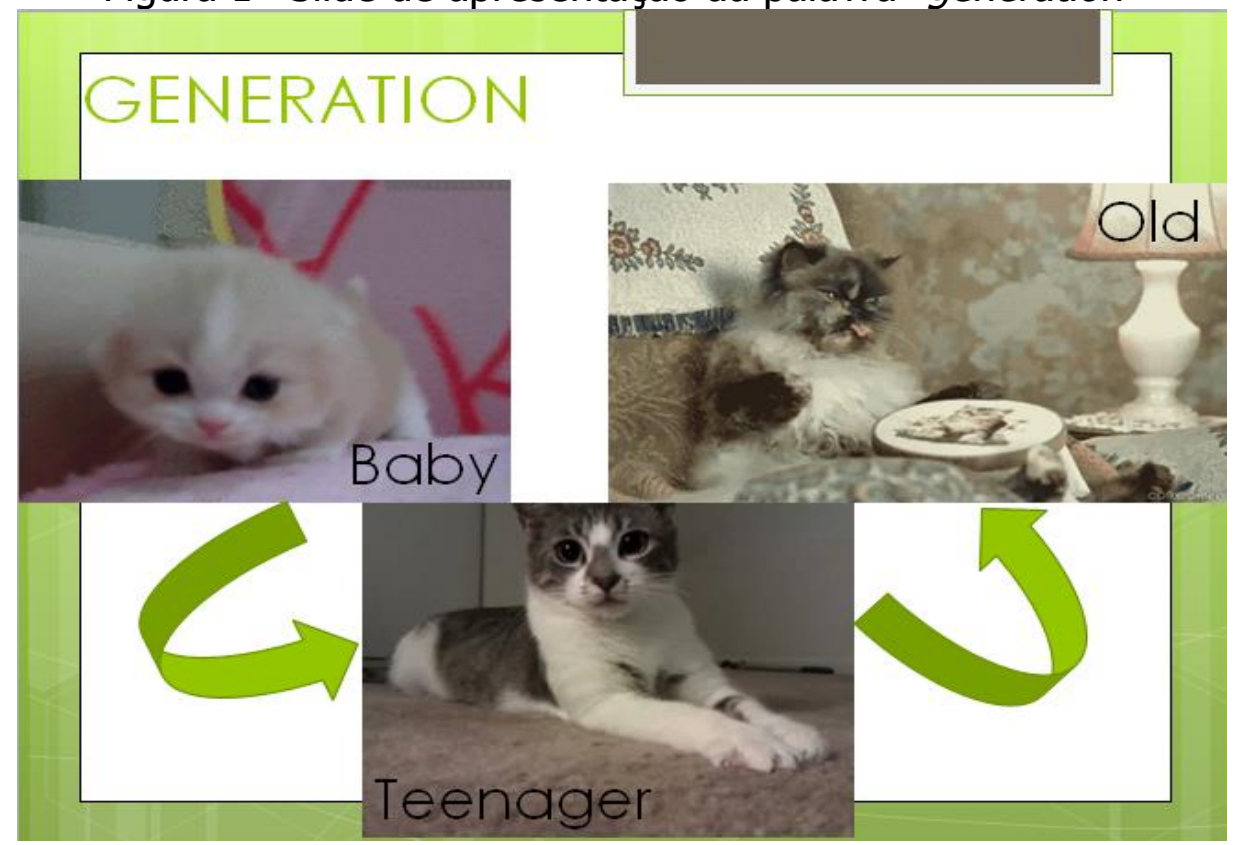

Fonte: Desenvolvido pelas autoras (2016). 
Figura 2 - Slide de apresentação da palavra "surprise"

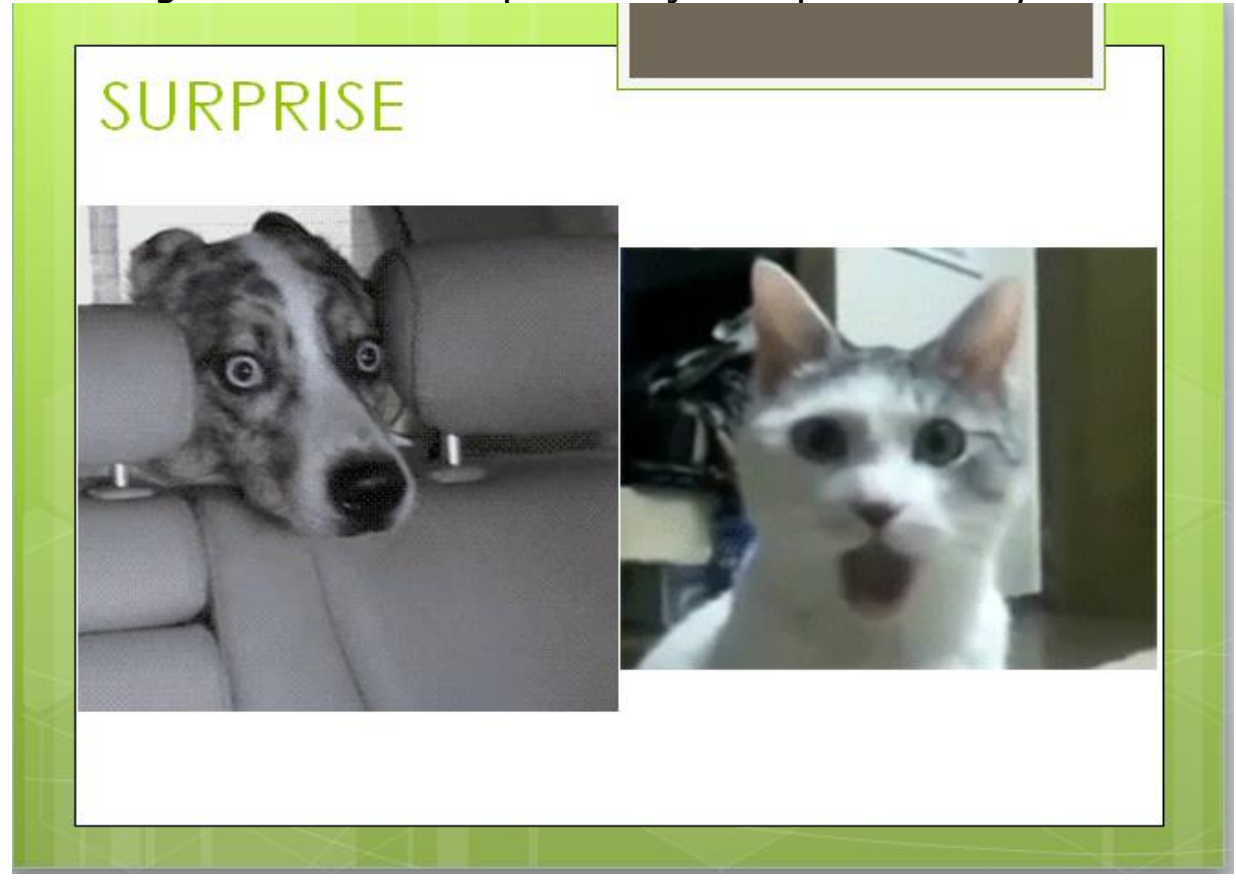

Fonte: Desenvolvido pelas autoras (2016).

Por meio dessa apresentação, os alunos foram expostos ao vocabulário de maneira dinâmica, atrativa e divertida, com constante prática da pronúncia dos vocábulos apresentados, sem tradução escrita nesse primeiro momento, apenas mencionada pela professora, com a intenção de levar os aluno à memorização a partir da visualização da palavra apenas em inglês, e simultânea conexão de seu significado com as imagens trazidas pelos GIFs nos slides, para que compreendesse o significado dessas palavras quando trazidas no conto.

Durante todas as atividades, os alunos foram instruídos a não anotar a tradução das palavras, tendo em vista que um dos objetivos do trabalho foi, também, a indução do aprendizado, levando os alunos a compreenderem a definição das palavras a partir de imagens e referências ao contexto em que foram utilizadas, apenas ouvindo a tradução de cada uma delas, o mínimo de vezes possível. Cada palavra foi repetida várias vezes ao longo da aplicação desta e de todas as atividades da sequência, de forma a levar a turma a reproduzir a pronúncia correta e promover a prática da fala do idioma de forma constante durante todas as aulas. Nesses momentos, várias dicas para melhorar a pronúncia foram apresentadas aos alunos, de acordo com fonemas 
específicos de cada vocábulo, explicitados e demonstrados pela professora e exercitados pelos estudantes.

Após a apresentação do vocabulário referente a um trecho do conto, um exercício impresso foi entregue ao grupo, para que completassem os espaços desse trecho com as palavras estudadas, ao mesmo tempo em que ouviam a gravação do conto. Quando necessário, o áudio era repetido, até que todos os alunos conseguissem completar os espaços em branco. Como em todas os exercícios da sequência, todos os alunos que fizeram a atividade obtiveram êxito, mesmo aqueles que não possuíam grande proficiência do idioma.

Para a correção do exercício, os mesmos parágrafos a serem completados foram expostos em slides, sendo que, primeiramente, a professora realizava a leitura em inglês e, no momento em que um espaço em branco era completado, o grupo respondia qual das palavras foi utilizada para completá-lo. Em geral, as respostas foram uniformes e os alunos conseguiram completar 0 exercício e participar da correção.

Com o intuito de compreender a história presente no excerto do conto, não apenas as palavras que já haviam sido trabalhadas de maneira diferenciada em slides, a tradução de cada parágrafo foi apresentada no slide. Esse foi o único momento em que foi necessário utilizar-se da tradução, devido à dificuldade de compreensão da linguagem da obra e do nível de conhecimento heterogêneo do idioma apresentado pelo grupo com que se trabalhava. A tradução apresentada nos slides foi feita pela própria autora deste trabalho.

Durante a comparação das versões do conto em inglês e em português, em que alguns alunos eram indicados para realizar a leitura da parte escrita em português, alguns detalhes sobre o enredo eram evidenciados com explicações nos próprios slides, para que ficasse mais clara a ambientação na história, como demonstrado pela Figura 3, em que algumas dessas explicações apareciam após a leitura do parágrafo, com a explicação simultânea da professora acerca do fato ressaltado. 
Figura 3 - Slide com explicações durante a Second Task

\section{2nd Task}

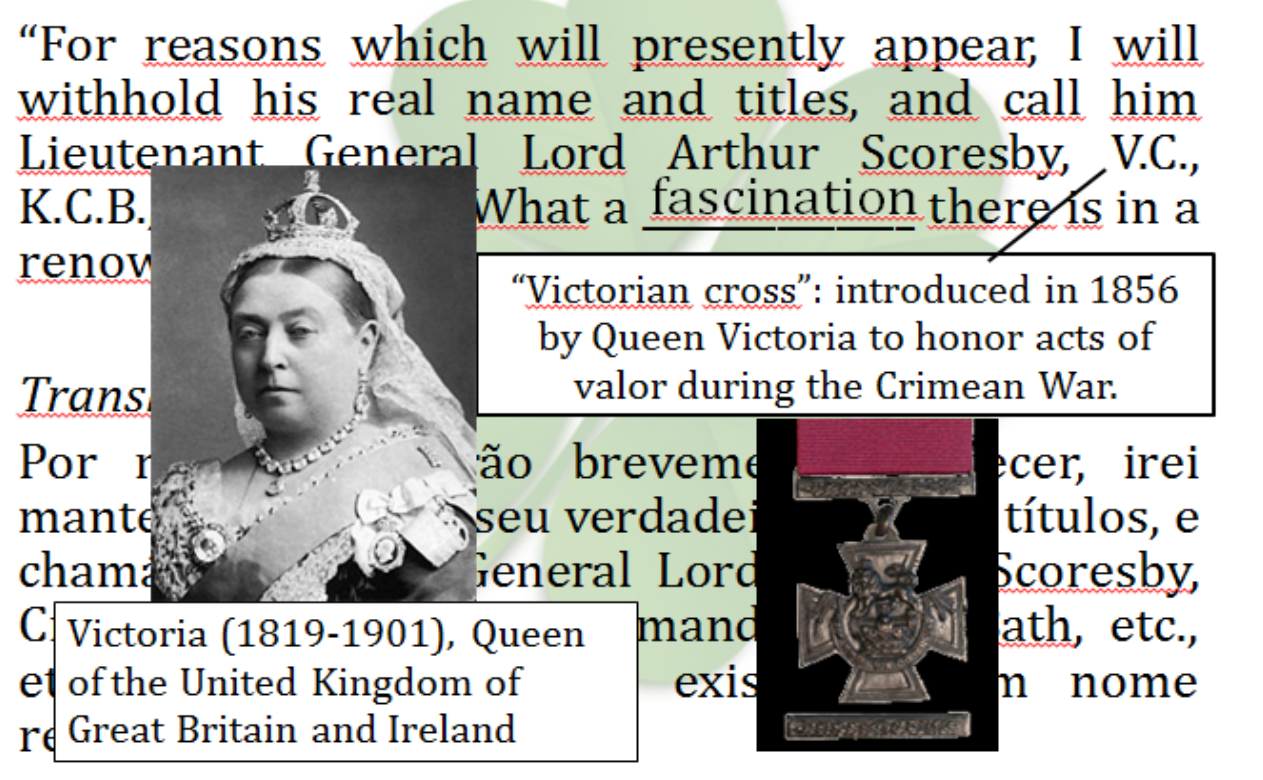

Fonte: Desenvolvido pelas autoras (2016).

As explicações apresentadas na Figura 3 referem-se ao título atribuído a um dos personagens principais do conto: o general Scoresby, que recebeu a titulação de "V.C.", abreviação de "Victorian Cross", que foi uma medalha destinada a heróis de guerra em honra a seus atos de valor durante a Guerra da Crimeia. Essa medalha passou a ser oferecida a partir de 1856, pela rainha Vitória, sobre a qual há, também, uma foto com uma breve explicação de seu reinado.

Ao final desse exercício impresso, um pequeno quadro com linhas, intitulado "short story's summary so far" ${ }^{\prime \prime}$, reservava o espaço para que cada aluno contasse, com suas próprias palavras, o que havia acontecido na história até então. Dessa forma, os alunos foram levados a concentrar-se na compreensão do conto. A turma foi instruída pela professora de que poderiam usar palavras em inglês nessa explicação individual. Alguns alunos conseguiram, inclusive, escrever seu resumo totalmente em inglês, por já apresentarem certo conhecimento da língua, tendo em vista que, segundo

\footnotetext{
6"Resumo do conto até agora" [Tradução nossa]
} 
Polidório (2004), um estudante pode adquirir vocabulário e compreender estruturas gramaticais com maior facilidade por meio de textos literários, o que muitas vezes acontece sem o aluno perceber de fato.

\section{A dinamicidade atribuída à proposta}

Uma das preocupações principais que permearam o desenvolvimento desse trabalho foi a atenção à dinamicidade da proposta. Conforme já apontado por Polidório (2004), o ensino de línguas nas escolas regulares tem se mostrado insatisfatório com relação ao desenvolvimento da habilidade comunicacional por meio de um estudo da língua estrangeira que envolva as quatro macro habilidades.

Geralmente, conforme Polidório (2004), os alunos que querem, de fato, comunicar-se por intermédio de outra língua matriculam-se em escolas particulares de ensino de idiomas, onde aprendem em grupos menores, usando um material diferenciado e dinâmico e professores que falam inglês durante toda a aula, sendo que a duração das aulas é duas vezes maior do que a carga horária de língua estrangeira na escola regular. $O$ autor afirma que todos esses fatores fazem com que os alunos se voltem a esses cursos de idiomas, para se tornarem realmente aptos a comunicar-se oralmente em outra língua.

Uma das maneiras de se engajar os alunos durante as atividades, nos momentos de leitura da tradução do conto, foi a indicação de vários alunos para que lessem a versão em português. Essa decisão permitiu que o momento de leitura não se tornasse algo voltado apenas à voz da professora, partindo da mesma premissa de utilização das diferentes vozes para as gravações do conto. Em todos os momentos de aplicação da proposta, tomou-se cuidado para envolver os alunos de maneira ativa durante as atividades, inclusive nos momentos de apresentações em PowerPoint ${ }^{\circledR}$. Ao utilizar-se essa ferramenta, devemos ter a consciência de como utilizá-la apropriadamente, ou seja, aproveitá-la de forma a tornar a apresentação mais dinâmica, e não mais monótona ou mecanizada, o que pode acontecer, caso se utilize essa 
ferramenta de maneira inapropriada, conforme exposto por Craig e Amernic (2006):

Our view is that whether a PowerPoint ${ }^{\circledR}$ presenter is the centre of attention or more of a stagehand will be a function of the communication ability of the presenter. Good presenters will most likely still be the centre of attention, using PowerPoint ${ }^{\circledR}$ appropriately as a valuable communication aid to buttress their rhetoric. Poor presenters, such as nervous freshman students making their first assessable class presentation, will most likely be stagehands, with PowerPoint ${ }^{\circledR}$ used as a dominating prop and their visual presence barely discernible. ${ }^{7}$ (CRAIG; AMERNIC, 2006, p. 151)

Outra dinâmica utilizada para os momentos de leituras, caracterizando-se como uma das mais simples, porém, mais proveitosa quanto ao engajamento dos alunos, foi a sincronização de palmas em grupo no momento de correspondência do vocabulário específico. Funcionou da seguinte maneira: para as correções dos exercícios, em que os alunos eram escolhidos para realizar a leitura em voz alta da versão em português de determinado parágrafo do conto, todos deveriam bater palmas juntos, no exato momento em que o leitor dissesse a tradução da palavra utilizada para responder ao exercício, conforme representado pela Figura 4, na sequência.

\footnotetext{
${ }^{7}$ Nossa visão é que, se um apresentador de PowerPoint ${ }^{\circledR}$ é o centro da atenção ou está mais para um assistente de palco será uma função da habilidade de comunicação do apresentador. Bons apresentadores muito provavelmente serão o centro da atenção, usando o PowerPoint ${ }^{\circledR}$ apropriadamente como um valioso auxílio de comunicação para reforçar sua retórica. Maus apresentadores, como alunos calouros nervosos realizando sua primeira apresentação avaliativa em classe, muito provavelmente serão assistentes de palco, com o PowerPoint ${ }^{\circledR}$ usado como um suporte dominante e tendo sua presença visual pouco perceptível. [Tradução nossa]
} 
Figura 4 - Slide pertencente à apresentação da Second Task

2nd Task

"It was at a banquet in London in honor of one of the two or three conspicuously illustrious English military names of this generation."

\section{Translation:}

"Foi em um banquete em Londres em honra a um dos dois ou três visivelmente ilustres nomes militares ingleses dessa geração."

Fonte: Desenvolvido pelas autoras (2016).

Conforme demonstrado na Figura 4, os alunos deveriam bater palmas juntos no momento em que as palavras "banquete" e "geração" fossem lidas pelo leitor do momento, as quais correspondem às traduções de "banquet" e "generation", palavras utilizadas para completar o exercício. Nas atividades que não eram de completar, como na Second Task, alguns vocábulos eram trazidos em negrito ao longo do texto no slide e apresentados pela professora, antes que se realizasse a leitura da versão em português. No momento da leitura, os alunos deveriam bater palmas ao ouvir a palavra correspondente àquela em negrito.

Para diferenciar ainda mais essa atividade, em alguns momentos as palmas aconteciam uniformemente, pelo grupo todo, enquanto, em outros momentos, dividiu-se a turma em mais grupos, para incitar a competição com relação a qual dos grupos seria o mais sincronizado nas palmas. Algumas vezes os grupos eram metade da turma, outras vezes eram divididos por filas. Essa atividade gerou grande animação por parte dos alunos, que se concentravam na leitura do colega para não perder o momento correto de bater palmas. 
Durantes todas as atividades, os exercícios foram aplicados por meio de dinâmicas como as que foram apresentadas no decorrer deste artigo.

\section{A percepção dos alunos acerca da proposta}

Para avaliar a percepção dos sujeitos envolvidos com relação ao trabalho realizado, considerou-se relevante avaliar, além da visão das pesquisadoras, as percepções provindas dos alunos envolvidos no trabalho realizado.

Para tanto, aplicou-se um questionário às turmas participantes. Prévia à aplicação do questionário, houve a aceitação do Comitê de Ética em Pesquisa (CEP), para que se iniciasse a coleta de dados. Para Lakatos e Marconi (2009), o questionário é um instrumento voltado à coleta de dados, constituído por perguntas ordenadas, que serão respondidas por escrito, fornecendo a vantagem de abordar um maior número de pessoas em um menor espaço de tempo, obtendo respostas mais rápidas e precisas, com mais segurança e menor risco de distorção.

As respostas a serem utilizadas para descrição dos resultados deste trabalho foram coletadas de 30 dos 64 questionários aplicados. Essa amostra de 30 alunos corresponde aos que nos forneceram o Termo de Consentimento Livre e Esclarecido (TCLE) assinado pelos seus respectivos responsáveis, permitindo-nos utilizar das respostas desses alunos nesta investigação. Ainda que não seja o total dos alunos participantes desta pesquisa, uma amostra de basicamente $50 \%$ do escopo geral é considerada estatisticamente grande e seus resultados podem ser extrapolados ao total geral com segurança.

A primeira questão do questionário levantou uma perspectiva geral sobre a percepção dos alunos acerca das atividades realizadas. Conforme consta no Gráfico 1, logo abaixo, 100\% da amostra respondeu "sim" à primeira questão: "Você considera as atividades realizadas sobre o conto Luck produtivas para a aprendizagem do inglês?" 
Gráfico 1 - Levantamento das respostas fornecidas à questão 1 do questionário

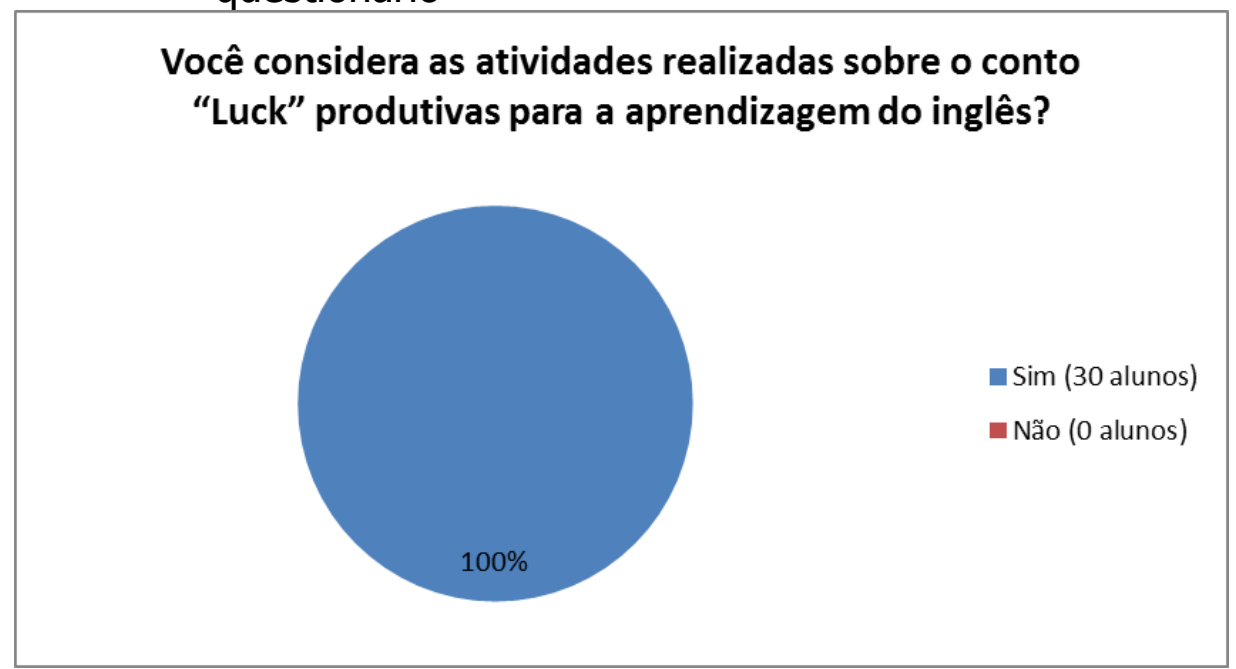

Fonte: Desenvolvido pelas autoras, a partir das respostas fornecidas aos questionários (2016).

A primeira pergunta consiste em uma questão aberta e, portanto, comentários individualizados foram tecidos por cada um dos alunos. As respostas fornecidas pelos trinta alunos, pertencentes à amostra, encontram-se explicitadas no Quadro 1, apresentada a seguir:

Quadro 1 - Respostas fornecidas à primeira questão do questionário

\begin{tabular}{|l|}
\hline $\begin{array}{l}\text { P1: Você considera as atividades realizadas sobre o conto Luck } \\
\text { produtivas para a aprendizagem do inglês? De que maneira essas } \\
\text { atividades podem auxiliar em seu estudo da língua? }\end{array}$ \\
\hline R1: Sim, pois é um meio de indução bem interessante \\
\hline R2: Sim \\
\hline R3: Sim \\
\hline R4: Sim, a aprendizagem fica fácil \\
\hline R5: Sim, induzindo a pessoa a ler em inglês e traduzir para entender \\
\hline $\begin{array}{l}\text { R6: Sim, podem auxiliar a entender as palavras do vocabulário e como se } \\
\text { pronuncia }\end{array}$ \\
\hline R7: Muito, mostraram o inglês verdadeira e intensivo \\
\hline R8: Sim, no compreendimento (sic) auditivo, escrito e na fala \\
\hline R9: Sim, pode auxiliar na aprendizagem do vocabulário \\
\hline R10: Sim, considero, pois esse conto me ajudou muito mais a entender a língua \\
\hline R11: Sim, elas mostraram como eu posso estudar sozinha e aumentar meu \\
vocabulário
\end{tabular}


R12: Sim, trazendo aprendizado inovador onde possa sair ganhando com novos conhecimentos

R13: Sim, pois aumentou meu vocabulário, apesar da dificuldade

R14: Sim, ajudando com o vocabulário e ouvindo em várias vozes diferentes para a melhor compreensão

R15: Sim, Muito produtivas e diferenciadas, ajuda bastante o estudo principalmente os vocabulários

R16: Sim. Eu acredito que trazer diferentes modos de aprendizado o torna menos entediante e traz mais interesse ao aluno

R17: Sim, conseguir traduzir, entender o que americanos falam, ou pelo menos uma base

R18: Sim, muito produtivas, porque ajuda a aumentar o vocabulário

R19: Sim, eu achei super produtivas, pois são coisas novas que eu nunca tinha visto. Me ajudaram conhecendo palavras novas

R20: Sim, são produtivas pois saem da rotina de todo dia ficar dentro da sala escrevendo no caderno

R21: Sim, elas podem nos ajudar a aprender vocabulário, aprender a falar, etc.

R22: Sim, facilita o aprendizado

R23: Sim, reforçando o vocabulário, etc.

R24: Sim, a repetição e ouvir ajuda no aprendizado

R25: Sim, pois a professora fez de uma forma de aprendizagem interessante e diferente, achei que foi ótimo assim

R26: Sim, pois foram atividades interativas que podem gerar curiosidades e mais interesses sobre o inglês

R27: Sim, aprendi novas palavras e como pronunciá-las, foi ótimo

R28: Sim, começando com palavras-chaves até conseguir entender um texto, foi isso que aprendi e vou tentar fazer em casa, assistindo filmes, ouvindo músicas e lendo textos

R29: Sim, com bastante dinâmica

R30: Sim, o conto contém um vocabulário diferenciado que nos ajuda a conhecer mais palavras

Fonte: Desenvolvido pelas autoras, a partir das respostas fornecidas aos questionários (2016).

Nessa primeira questão, os comentários refletem uma perspectiva positiva uniforme, proveniente das respostas escritas pelo grupo. Vários comentários ressaltam benefícios quanto à interatividade, às dinâmicas, ao vocabulário, aos exercícios indutivos, à simplificação do processo de aprendizagem e à diferenciação do método utilizado. Como se pode perceber, 
nenhum comentário apresentou considerações negativas quanto à aplicação do trabalho.

Para uma melhor visualização das respostas fornecidas pelos alunos, os comentários foram classificados em diferentes categorias, expostas pelo Gráfico 2, apresentado a seguir:

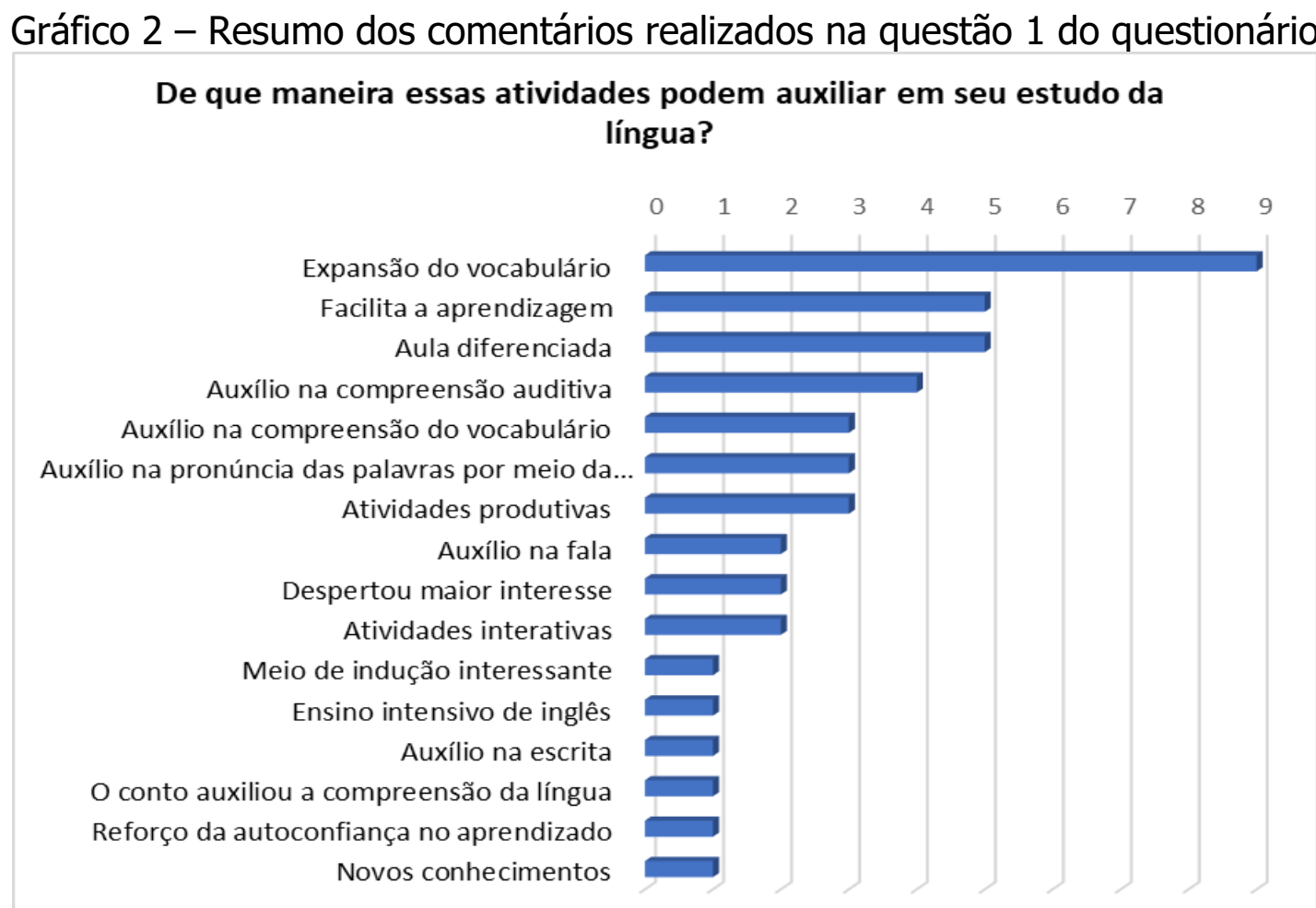

Fonte: Desenvolvido pelas autoras, a partir das respostas fornecidas aos questionários, 2018

$\mathrm{Na}$ interpretação dos comentários dos alunos, levou-se em conta cada aspecto mencionado, sendo que muitos dos alunos mencionaram mais do que apenas um ponto positivo a ser destacado em sua percepção quanto às atividades realizadas. As categorias criadas para resumir as respostas dos alunos, seguidas do número de comentários que as mencionaram direta ou indiretamente, foram: expansão do vocabulário (9); facilita a aprendizagem (5); aula diferenciada (5); auxílio na compreensão auditiva (4); auxílio na compreensão do vocabulário (3); auxílio na pronúncia das palavras por meio da repetição (3); atividades produtivas (3); auxílio na fala (2); despertou maior interesse (2); atividades interativas (2); meio de indução interessante (1); 
ensino intensivo de inglês (1); auxílio na escrita (1); o conto auxiliou a compreensão da língua (1); reforço da autoconfiança no aprendizado (1); novos conhecimentos (1).

No que se refere aos benefícios da dinamicidade, a qual promove a interação do grupo - uma das vantagens comentadas pelos alunos em suas respostas - Rivers (1987) considera essa interação não apenas benéfica, mas imprescindível para o aprendizado da LE. Conforme a autora, é a partir da interação que os alunos são capazes de aumentar seu conhecimento quanto à língua, enquanto ouvem ou escutam materiais linguísticos autênticos, ou participam de discussões abordando as diferentes compreensões apresentadas pelo grupo. Mais uma vez, agora considerando as afirmações de Rivers (1987) quanto à importância da interação, ressalta-se uma das premissas desta proposta: produzir o conhecimento a partir da interação, de maneira dinâmica e diferenciada.

Seguindo na análise das respostas aos questionários, a segunda pergunta abordou quais foram os principais aspectos positivos com relação ao desenvolvimento da prática, na perspectiva dos alunos, a partir do seguinte questionamento: "Em sua opinião, quais foram os aspectos positivos com relação às atividades realizadas?" Como se trata de uma questão aberta, os comentários, aqui, também correspondem a perspectivas individuais, conforme apresentado no Quadro 2, na sequência.

Quadro 2 - Respostas fornecidas à segunda questão do questionário

P2: Em sua opinião, quais foram os aspectos positivos com relação às atividades realizadas?

R1: Ajudou na pronúncia e no entender no som de escutar

R2: A aula pareceu mais dinâmica, mais divertida

R3: Ajudando na pronúncia e tradução de algumas palavras

R4: Aprendi bem mais e me diverti

R5: A dinâmica

R6: Compreender a pronúncia, e ajuda a entender o significado das palavras

R7: Leitura; Aprendizado; Interação; Novas perspectivas

R8: As palavras novas, pronúncias, escrita, compreensão auditiva

R9: Uma aula diferenciada com muitas atividades e pronunciar corretamente as 
palavras

R10: As novas palavras que aprendi, que também aprendi a pronunciá-las corretamente

R11: Com elas pude perceber que o inglês não é tão difícil. Elas foram legais.

R12: A professora em si sempre extrovertida, carismática, atenciosa, o que faz com que tenha alunos com bastante conhecimento

R13: Me fez acreditar que eu tenho capacidade de aprender inglês sozinha, mesmo fazendo cursos

R14: O fato de ser uma aula com materiais diferenciados e por treinarmos o inglês ouvindo

R15: Aprendizado dos vocabulários; interação na sala

R16: Abordar esse assunto, ao mesmo tempo que aprendemos inglês, vimos um pouco da história e da literatura inglesa

R17: Foi bom, bem descontraído e ao mesmo tempo explicativo

R18: Aprender novas pronúncias, novas palavras, e uma história nova

R19: A teacher super dedicada, trazendo atividades diferentes e fazendo nós alunos repetir as palavras que não sabíamos

R20: Uso de slides

R21: Me ajudou a entender tudo de uma forma mais fácil

R22: A explicação e o desenvolvimento

R23: A maneira de ensinar, e a interação com a turma

R24: Comunicação e forma de aplicação dos conteúdos

R25: Os aspectos positivos foram repetir com a professora e ajuda a memorizar de uma forma diferente. As aulas foram ótimas.

R26: Foram atividades legais, fáceis de compreender.

R27: Foram aspectos muito bons, aprendi muito nessas aulas, mais do que nas aulas com as outras professoras

R28: A repetição de palavras-chaves eu gostei muito, porque quanto mais repetimos, mais aprendemos. As aulas foram ótimas e aprendi muito.

R29: As atividades que tiveram as pessoas falando para encontrar as respostas R30: Em relação aos áudios e o método que foi utilizado facilitou o nosso aprendizado

Fonte: Desenvolvido pelas autoras, a partir das respostas fornecidas aos questionários (2016).

Dentre as respostas fornecidas para essa segunda questão, diversos comentários voltaram-se à prática da repetição, à dinamicidade, à prática auditiva, ao trabalho da professora, ao ensino da literatura e à interação em sala de aula. Mais uma vez, os comentários mostraram-se elogiosos com relação ao trabalho desenvolvido com as turmas. Os termos "dinâmica", "interação" e "diversão" foram mencionados por 7 alunos, aproximadamente 23\% da amostra. 
O Gráfico 3 apresenta uma classificação dos comentários tecidos à questão 2, ressaltando os aspectos positivos mais frequentemente mencionados. Os pontos destacados e a frequência com que foram mencionados estão dispostos nas seguintes classificações: dinamicidade e interação (12); auxílio na pronúncia por meio da repetição de palavras (9); uma aula diferenciada (9); compreensão do vocabulário (6); auxílio na compreensão auditiva (4); auxílio no aprendizado da língua inglesa (4); facilidade no aprendizado (4); explicação clara (2); prática da leitura (1); prática da escrita (1); reforço da autoconfiança no aprendizado (1); estudo da Literatura de língua inglesa (1); as questões históricas abordadas no conto (1); a história do conto (1); uso de slides (1).

Gráfico 3 - Resumo dos comentários realizados na questão 2 do questionário

Em sua opinião, quais foram os aspectos positivos com relação às atividades realizadas?

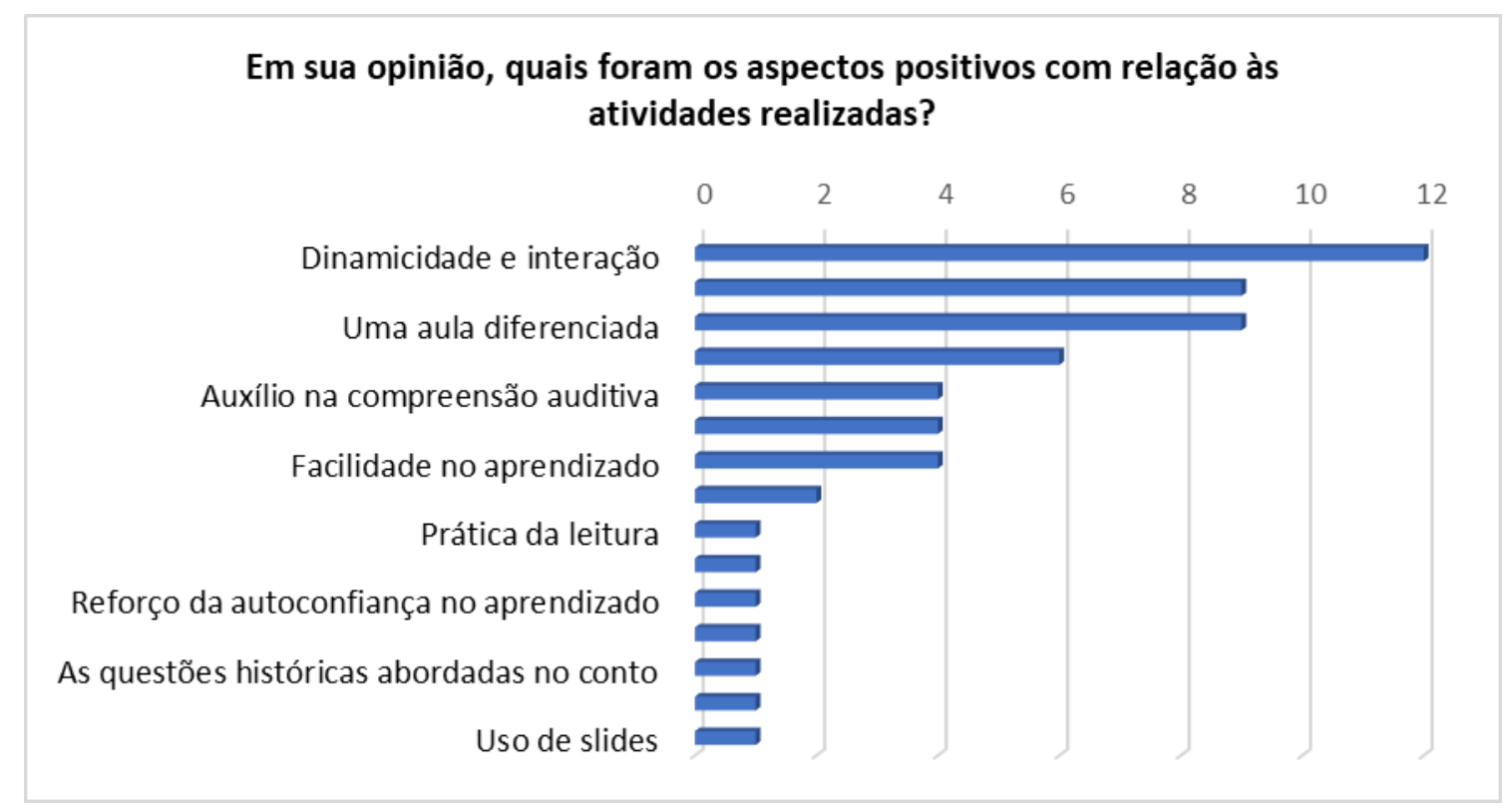

Fonte: Desenvolvido pelas autoras, a partir das respostas fornecidas aos questionários (2018).

Em meio às respostas, alguns dos comentários merecem destaque, ao ressaltarem-se os objetivos almejados desde o início deste trabalho, como "Com elas pude perceber que o inglês não é tão difícil" e "Me fez acreditar que eu tenho capacidade de aprender inglês sozinha". Uma das principais motivações, que nos guiou ao desafio de criar um projeto diferenciado de 
ensino da língua inglesa foi, de fato, a intenção de tornar os momentos da aula de língua estrangeira em fatores catalisadores da motivação e do incentivo ao estudo de outro idioma. No comentário "ao mesmo tempo que aprendemos inglês, vimos um pouco da história e da literatura inglesa", percebe-se outra das intenções primordiais da proposta: o ensino da literatura de língua inglesa, vinculado ao ensino da língua inglesa. Os comentários destacados demonstram uma aceitação por parte destes alunos quanto à nossa intenção de motivá-los e encorajá-los ao autodidatismo no estudo da língua inglesa, além do contato com a literatura estrangeira.

Além disso, tais comentários mostram-se em conformidade com a noção trazida por Polidório (2004), de que, quando os alunos se sentem confiantes com relação ao que estão aprendendo, desenvolvem suas habilidades mais rapidamente do que situações em que não se sentem confortáveis com a matéria. Quer dizer, o aluno deve sentir-se seguro com a língua que estuda. Ademais, a literatura possibilita que essa segurança aumente, envolvendo conhecimentos que os alunos já possuem, com a língua em estudo. Segundo o autor, para aprender mais sobre algo, as pessoas precisam sentir-se livres para expressar suas próprias opiniões e sentimentos, o que pode ser possível por meio da literatura.

A terceira pergunta do questionário aborda os aspectos negativos percebidos pelos estudantes. Para análise das respostas obtidas nesta pergunta, classificaram-se as respostas em 5 categorias, de acordo com os comentários discorridos pelo grupo, conforme demonstrado pelo Gráfico 4, abaixo: 
Gráfico 4 - Levantamento das respostas fornecidas à questão 2 do questionário

\section{E quanto aos aspectos negativos?}

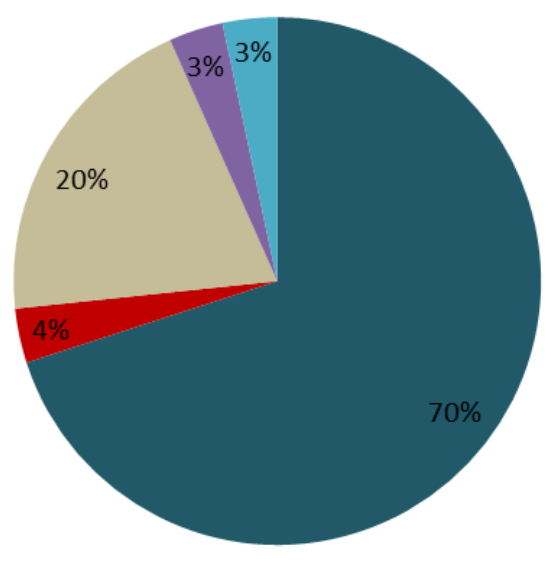

- Não/Nenhum

(21 alunos)

- Complexidade da história

(1 aluno)

Pouco tempo de aula (6 alunos)

- Pronúncias difíceis, como a do "th", em específico (1 aluno)

- Vocabulário muito avançado (1 aluno)

Fonte: Desenvolvido pelas autoras, a partir das respostas fornecidas aos questionários (2016).

Nessa questão referente aos aspectos negativos, a maior parte das respostas apontou a inexistência de aspectos negativos na proposta, o que representa, mais uma vez, uma perspectiva crítica positiva dos alunos com relação ao trabalho, totalizando uma parcela de $70 \%$ da amostra que afirmou não haver qualquer fator negativo relevante. Para os outros $30 \%$ da amostra, os fatores negativos apresentaram ressalvas quanto à reduzida duração da carga horaria disponível para a implementação das atividades propostas nesta sequência didática; às dificuldades de pronúncia, em especial as fricativas interdentais referentes ao som do "th", que pode ser representado pelos fonemas $/ \varnothing /$ e $/ ð /$, sendo este sonoro e aquele surdo; à complexidade da história; e ao nível do vocabulário presente no conto, considerado muito elevado para o conhecimento prévio da língua que alguns dos alunos possuíam.

Com relação às dificuldades apontadas para as pronúncias, é comum que os alunos apresentem relutância quanto às diferenciações nas articulações pertencentes a outro idioma, em especial quando se trata de uma articulação específica não existente em sua língua nativa, como é o caso das fricativas interdentais representantes da combinação das letras "th" no inglês. 
Ao decidir executar a proposta elaborada em turmas de uma escola regular, nas quais os níveis de proficiência do idioma apresentaram-se completamente heterogêneos entre os alunos, esperava-se, desde o princípio, certa relutância por parte de alguns alunos quanto ao material escolhido: um conto original, sem qualquer adaptação que facilitasse o processo de entendimento. Por isso, alguns dos apontamentos levantados nesta questão consideraram o nível do material utilizado como alto, quanto à complexidade da história e ao vocabulário nela apresentado, segundo a percepção de alguns alunos. Mesmo assim, vale ressaltar as diferentes razões que nos levaram a optar pelo conto original para o desenvolvimento do trabalho, razões, estas, a serem descritas a seguir.

A relação de ensino/aprendizagem proposta pelo presente trabalho busca, entre seus principais objetivos, romper com o usual. Diferenciar-se, desde a escolha dos materiais, até a maneira como seriam aplicados. Assim sendo, não apenas se vinculou o ensino da língua estrangeira inglesa ao ensino da literatura de língua inglesa, o que já representa, por si só, um desafio; mas, além disso, buscou-se fazê-lo de forma a valorizar a literatura como o objeto social que ela representa. Para tanto, considera-se essencial ausentar a proposta de qualquer modificação na obra literária original escolhida, pois isto poderia significar a transformação, em certo nível, da verdadeira intenção provinda do autor ao escrevê-la, além de desclassificá-la como um material original, de fato, o que não seria condizente com nossas intenções, ao trazer a literatura, em sua verdadeira forma, à aula de idioma.

Para Polidório (2004), a literatura também é uma maneira de se ensinar a língua, não há como considerá-las esferas individuais distintas. Mesmo assim, é necessário usar a literatura de maneira adequada, encontrando maneiras de auxiliar os alunos a aprenderem o idioma por meio de obras literárias. Ainda segundo o autor, não há uma única maneira certa para se usar textos literários no ensino da língua, pois cada turma pode ser diferente, assim como cada obra. O papel do professor é fornecer o suporte necessário para que o aluno seja capaz de ler determinado material. 
Dessa maneira, o uso do conto sem adaptações justifica-se pela intenção de utilizar a obra literária escolhida em sua forma original. Caso se utilizasse outra versão, não corresponderia, de fato, à verdadeira obra de Mark Twain (1892), mas sim a uma nova versão criada a partir da original, o que não condiz com as intenções propostas. Além do mais, a escolha de trabalhar com a versão original do conto expandiu, ainda mais, o desafio designado pela proposta. Mesmo assim, as maneiras encontradas para se trabalhar com 0 material possibilitaram que os alunos conseguissem resolver todos os exercícios propostos (independentemente de seu nível de proficiência no idioma), que compreendessem a história e, por fim, trouxessem vários comentários com respeito à execução da proposta, o que pode ser percebido na análise geral das respostas aos questionários.

Outro diferencial da proposta foi a realização de exercícios sem a tradução escrita. Os exercícios foram realizados de maneira indutiva e não propuseram qualquer tipo de tradução escrita do aluno. 0 único momento em que se optou por utilizar da tradução foi na apresentação das correções dos exercícios por meio dos slides, na intenção de auxiliar a compreensão de todos os alunos - mais uma vez independentemente de seu nível de proficiência do idioma. No entanto, a tradução só era exposta depois de os alunos serem instigados a compartilhar o que haviam compreendido de cada trecho.

A quarta e última pergunta questionou os alunos quanto às inúmeras dicas fornecidas pela professora ao longo das aulas, as quais foram, em sua maioria, relacionadas à aprendizagem da língua inglesa de maneira autônoma. Para a pergunta específica "Você considera produtivas as dicas para aprender inglês que foram fornecidas pela professora durante as aulas?", a totalidade das respostas foi "sim", como mostra o Gráfico 5, abaixo: 
Gráfico 5 - Levantamento das respostas fornecidas à questão 3 do questionário

Você considera produtivas as dicas para aprender inglês que foram fornecidas pela professora durante as aulas?

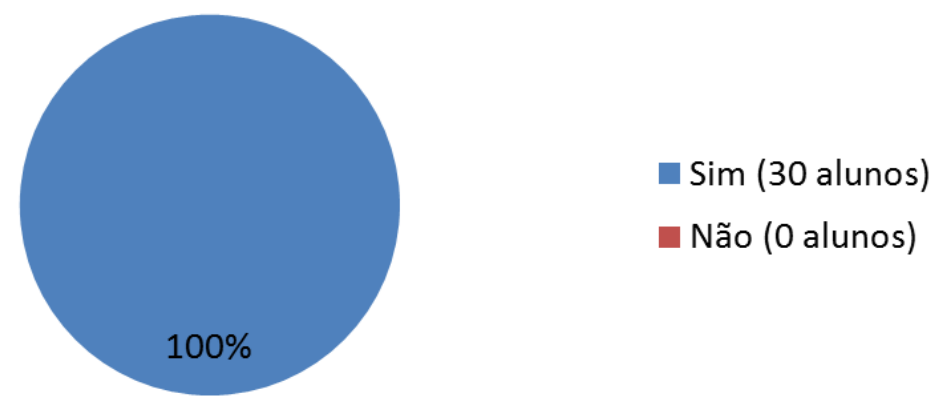

Fonte: Desenvolvido pelas autoras, a partir das respostas fornecidas aos questionários (2016).

Na sequência dessa mesma pergunta, alguns comentários foram tecidos pelos alunos, seguindo à continuação da pergunta: "Você pretende seguir alguma(s) dela(s)? Qual(is)?". Os comentários estão presentes no Quadro 3, apresentado na sequência.

Quadro 3 - Respostas fornecidas à questão 4 do questionário

\section{P3: Você pretende seguir alguma(s) dela(s)? Qual(is)?}

R1: Pretendo usar todas

R2: A de assistir séries em inglês com legenda em inglês também

R3: Assistir filmes e séries com legenda ou áudio em inglês

R4: Ouvir músicas, assistir e vir mais vezes

R5: Assistindo filmes em inglês

R6: Pretendo continuar a ler contos ou séries da língua para auxiliar meu aprendizado

R7: Todas e sou muito grato

R8: Assistir filmes e séries legendadas, músicas em inglês, duolingo, etc.

R9: Pretendo assistir mais filmes em inglês e ouvir músicas pesquisando a tradução

R10: Praticar todos os dias com séries, filmes, app

R11: Pretendo ver mais séries e aumentar meu vocabulário

R12: Pretendo seguir algumas delas, como assistir filmes e séries com a legenda em inglês e aumentar meu contato com o inglês de todas as formas 
possíveis

R13: Assistir séries em inglês, ouvir música e etc.

R14: Ouvir mais músicas em inglês e ver filmes e séries em inglês

R15: Já sigo algumas como ver letras de músicas e assistir séries sem legendas

R16: A respeito de ver mais séries em inglês, tentar interpretar mais coisas sozinho

R17: Quando eu tenho tempo eu traduzo músicas. E também baixei o Duolingo. Thanks, teacher!

R18: A começar a ver séries e filmes sem a legenda em português para aprofundar meu conhecimento

R19: As dicas são boas para quem não tem condições financeiras de pagar um curso

R20: Pretendo ouvir músicas e depois ver a tradução, assistir séries sem legendas, baixar aplicativos, entre outros

R21: Não

R22: Usar os programas que traduzem 0 inglês para o português, como legenda, etc

R23: Por se tratar de dicas que podem ser utilizadas no dia a dia

R24: Eu não pensei no que quero definitivamente, mas do jeito que aprendemos, dá mais vontade de pensar no futuro.

R25: Pretendo baixar aplicativos e enriquecer meu vocabulário

R26: Eu já sigo elas e vou continuar seguindo, são ótimas dicas

R27: Com certeza tudo o que a professora ensinou, desde repetir palavras até sublinhar palavras que eu não sei e treiná-las

R28: Jogos em inglês, músicas, filmes e séries

R29: Sim, pretendo usar todas

R30: Eu pratico algumas delas no meu dia a dia e vejo resultados

Fonte: Desenvolvido pelas autoras, a partir das respostas fornecidas aos questionários (2016).

As respostas à questão 3 também foram classificadas em categorias, de acordo com o Gráfico 6, na sequência. Os comentários envolveram a seguinte frequência de respostas: Praticar com filmes e/ou séries com áudio e/ou legenda em inglês (16); praticar com músicas em inglês (9); pretendo utilizar todas (4); utilizar aplicativos de ensino da língua inglesa (3); utilizar o aplicativo Duolingo (2); ler outros contos em inglês (1); nenhuma (1); repetição de palavras (1); sublinhar palavras novas (1); jogos em inglês (1). 
Gráfico 6 - Resumo dos comentários realizados na questão 3 do questionário

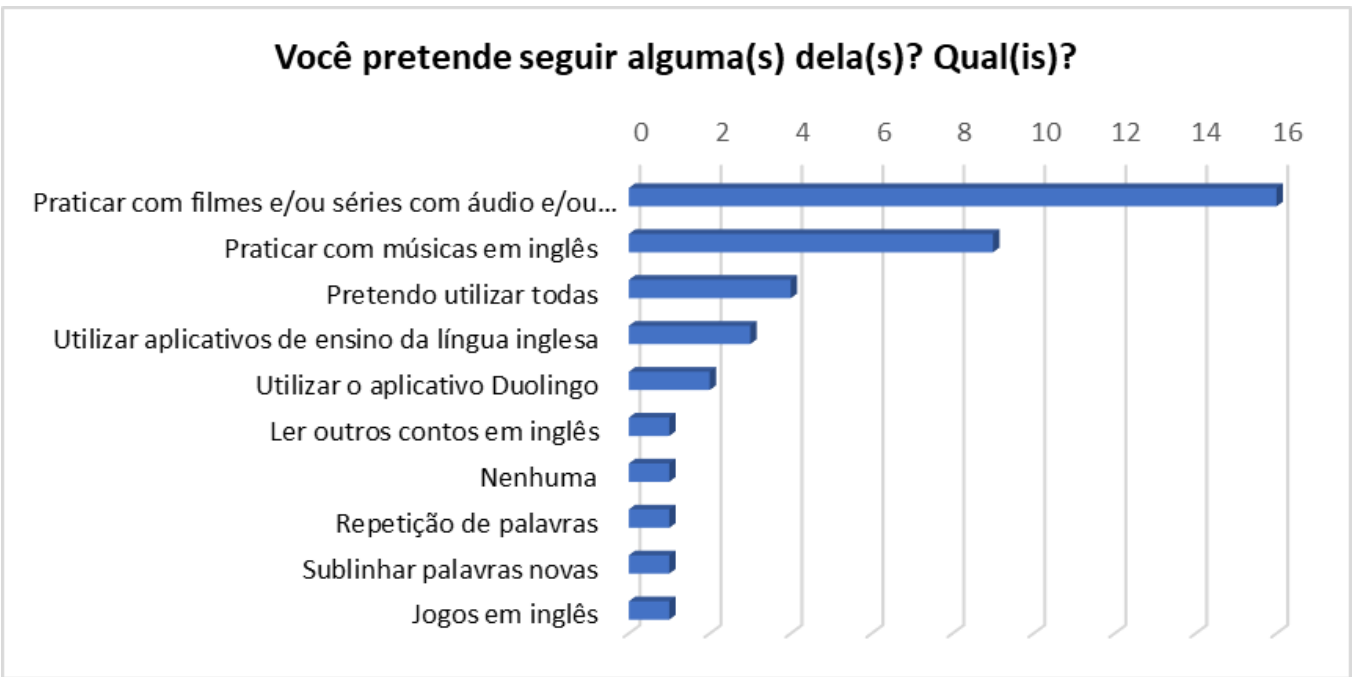

Fonte: Desenvolvido pelas autoras, a partir das respostas fornecidas aos questionários (2018).

Como se pode perceber, a grande maioria dos alunos afirmou sua pretensão em usar as dicas propostas para o estudo autônomo da língua inglesa, como o uso de séries e filmes com o áudio e legendas em inglês, os aplicativos de celular que auxiliam o aprendizado do idioma, a prática com músicas e com jogos, dentre outros. Apenas um dos alunos não demonstrou intenção de seguir as dicas de estudo. Deve-se lembrar, em momentos como esse, que o trabalho do professor, geralmente, abrange um grande número de indivíduos, com diferentes crenças, objetivos e características pessoais. Mesmo que a maioria das respostas obtidas tenha apresentado uma perspectiva enaltecedora sobre os benefícios do trabalho realizado, é de se esperar que o grupo participante da proposta não seja unânime em suas convicções, assim como em sua percepção quanto ao estilo adotado para o processo de ensino desta sequência.

\section{Reflexões acerca dos resultados da proposta aplicada}

A elaboração e execução deste trabalho representou uma jornada produtiva e gratificante, da qual, como resultado, demonstrou-se uma forma exequível de se trabalhar um conto original provindo da literatura de língua 
inglesa com alunos do ensino médio de uma escola pública. O desafio de se elaborar uma sequência didática utilizando um texto de nível avançado no idioma estrangeiro em estudo, para uma turma de níveis heterogêneos de proficiência em inglês, elevou o trabalho à altura das expectativas almejadas pela proposta, sendo que, ao longo do processo, percebeu-se que os propósitos foram alcançados. Atividades diversificadas foram elaboradas e executadas com sucesso, utilizando-se de detalhes únicos ao longo de sua aplicação, como as dinâmicas, a temática das aulas, a compreensão do conto, os debates acerca da história, a prática do vocabulário apresentado, dentre outras práticas.

Para que as atividades ocorressem de forma a atrair a atenção de todos os sujeitos envolvidos e para, dessa forma, promover a prática das quatro macro habilidades do processo de ensino-aprendizagem de línguas (fala, escrita, leitura e compreensão oral), percebeu-se que o maior diferencial consistiu na dinamicidade com que as atividades foram apresentadas. As dinâmicas, os objetos digitais de apresentação utilizados, as imagens e sons representaram, em sua amplitude, elementos primordiais para o sucesso da aplicação dessa sequência didática.

Além de participarem das atividades, os alunos levantaram questionamentos interpretativos sobre a história, participaram de todas as dinâmicas, trouxeram questões quanto ao uso da língua presente no conto trabalhado, além de, informalmente, realizarem comentários positivos com relação às práticas utilizadas durante as aulas, como a prática da repetição da pronúncia correta das palavras, um dos pontos tratados com maior entusiasmo pelos alunos, e a interdisciplinaridade de ensino entre a língua inglesa e a literatura de língua inglesa. A percepção dos alunos quanto à proposta tornouse ainda mais clara a partir da análise dos questionários aplicados para se verificar os resultados obtidos com o trabalho, na visão dos alunos.

Assim sendo, a exposição da forma como o presente trabalho foi elaborado e executado traz consigo não apenas uma conclusão que por aqui finda, mas também uma possibilidade de levar adiante as práticas que aqui se demonstraram benéficas para o ensino da literatura e do idioma estrangeiro, 
em especial a dinamicidade que diferentes recursos possibilitaram, unidos ao papel do professor ao utilizá-los de maneira adequada, resultando, assim, em uma aula atrativa e interacional que se utiliza da interdisciplinaridade também como um de seus diferenciais.

\section{Referências}

BAKHTIN, Mikhail. Estética da criação verbal. São Paulo: Martins Fontes, 1992.

BEZERRA, Maria Auxiliadora. O ensino de língua numa perspectiva interdisciplinar. In: SANTOS, Hérika Ribeiro; ANDRELINO, Paulo José (Org.). Linguagens em interação II: leitura e ensino de línguas. Maringá: Clichetec, 2010.

BORDINI, Maria da Glória; AGUIAR, Vera Teixeira. Literatura: a formação do leitor. 2. ed. Porto Alegre: Mercado Aberto, 1993.

BRASIL. Ministério da Educação. Secretaria de Educação Média e Tecnológica. Parâmetros curriculares nacionais: ensino médio. Brasília: MEC, 2000.

BRITO, Edivaldo. O que é GIF? Revista Techtudo, 2013. Disponível em: <http://www.techtudo.com.br/artigos/noticia/2012/04/o-que-e-gif.html> Acesso em: 3 ago. 2016.

CRAIG, Russel J.; AMERNIC, Joel H. Powerpoint ${ }^{\circledR}$ presentation technology and the dynamics of teaching. Innovative Higher Education, Athens, v. 31, p. 147160, 2006. Disponível em: <http://link.springer.com/article/10.1007/s10755006-9017-5> Acesso em: 26 nov. 2016.

DOLZ, Joaquim; NOVERRAZ, Michele; SCHNEUWLY, Bernard. Seqüências didáticas para o oral e a escrita: apresentação de um procedimento. In: SCHNEUWLY, Bernard et al. Gêneros orais e escritos na escola. Campinas: Mercado de Letras, 2004. p. 95-118.

GANTIER, Hélène. O ensino de uma língua estrangeira: presses universitaires de France, 1968. Tradução de Maria Flôr Marques Simões. 2. ed. Lisboa: Estampa, 1974.

LAKATOS, Eva Maria; MARCONI, Marina de. Fundamentos de metodologia científica. São Paulo: Atlas, 2009.

MOTTER, Rose Maria Belim. My way: um método para o ensino aprendizagem de língua inglesa. 2013. Tese (Doutorado em Engenharia e Gestão do Conhecimento) - Universidade Federal de Santa Catarina, Florianópolis, 2013. 
POLIDÓRIO, Valdomiro. The use of literature in the english teaching. Cascavel: Coluna do Saber, 2004.

RIVERS, Wilga M. Interactive language teaching. New York: Cambridge University Press, 1987.

SMITH, James A. Creative teaching of reading and literature in the elementary school. Boston: Allyn and Bacon, 1967.

TWAIN, Mark. Luck. In: . The american claimant and other stories and sketches. Nova Iorque: P. F. Collier \& Son, 1892. Disponível em:

<http://www.classicshorts.com/stories/luck.html>. Acesso em: 16 jun. 2018. 